\title{
HMOX1 wt Allele
}

National Cancer Institute

\section{Source}

National Cancer Institute. HMOX1 wt Allele. NCI Thesaurus. Code C50881.

Human HMOX1 wild-type allele is located within $22 q 12$ and is approximately $13 \mathrm{~kb}$ in length. This allele, which encodes heme oxygenase 1 protein, plays a role in the conversion of heme to bilirubin and carbon monoxide. Certain allelic variants of the HMOX1 gene are associated with heme oxygenase 1 deficiency. 